\title{
ÓsCAR PÉREZ (1981-2018): Chronicle of a Death Foretold
}

\author{
AlLan Deneuville* \\ University Paris 8, France / University of Québec in Montreal, Canada \\ deneuville.a@gmail.com
}

Recibido: 14/5/2020 Aceptado: 24/8/2020

DOI: https://doi.org/10.26439/contratexto2020.n034.4866

\begin{abstract}
In this article, we propose the comparative study of two works that use videos of Venezuelan political opponent Óscar Pérez who was killed during a military raid. Romain Champalaune's film (The Life and Death of Óscar Pérez) and the website of the British collective Forensic Architecture question us about the future of user-generated content and the place of the artist and the researcher in the society of hyperproduction of texts and documents. After introducing the Pérez case and presenting the works, we analyze the regime of proof and the idea of truth and the archive in the era of algorithmic governmentalities. Finally, we study how investigation and the collection of user-generated content allow for a shift in our power regimes through the implementation of counternarrative to that of the powers that be.
\end{abstract}

Keywords: Óscar Pérez / monster-archive / counter-narrative / user-generated content / captopticon

\section{ÓSCAR PÉREZ (1981-2018): CRÓNICA DE UNA MUERTE ANUNCIADA}

Resumen. En este artículo, proponemos el estudio comparativo de dos obras que utilizan los videos del opositor político venezolano Óscar Pérez que fue asesinado durante una incursión militar. La película de Romain Champalaune y el sitio web del colectivo británico Forensic Architecture nos cuestionan sobre el futuro del contenido generado por el usuario y el lugar del artista y el investigador en la sociedad de la hiperproducción de textos y documentos. Después de presentar el caso Pérez y las obras, analizamos el régimen de la prueba y la idea de la verdad y el archivo en la era

\footnotetext{
*PhD candidate in Comparative Literature and media studies at the University Paris 8, France. (see: https:// orcid.org/0000-0002-8936-9490).
} 
de las gubernamentalidades algorítmicas. Finalmente, estudiamos cómo la investigación y la colección de contenidos generados por los usuarios permiten un cambio en nuestros regímenes de poder a través de la implementación de la contra-narración a la de los poderes fácticos.

Palabras clave: Óscar Pérez / monstruo-archivo / contra-narración / contenidos generados por usuarios / captopticon

\section{ÓSCAR PÉREZ (1981-2018): CRÔNICA DE UMA MORTE ANUNCIADA}

Resumo. Neste artigo propomos o estudo comparativo de dois trabalhos que utilizam os vídeos do opositor político venezuelano Óscar Pérez, quem foi morto durante uma incursão militar. 0 filme de Romain Champalaune e o site do coletivo britânico Forensic Architecture nos questionam sobre o futuro do conteúdo gerado pelo usuário e sobre o lugar dos artistas e dos pesquisadores na sociedade da hiperprodução de textos e documentos. Após a apresentação do caso Pérez e das obras, analisamos o regime de prova e a ideia de verdade e de arquivo na era dos governamentalidades algorítmicos. Finalmente, estudamos como a investigação e a coleta de conteúdo gerado pelos usuários permitem uma mudança nos nossos regimes de poder através da implementação da contra-narração como contraposição dos poderes de fato.

Palavras-chave: Óscar Pérez / monstruo-arquivo / contra-narracão / conteúdo gerado pelo usuário / captopticon 


\section{WHO IS ÓSCAR PÉREZ?}

On January 15, 2018, thousands of people witnessed the live execution of Óscar Pérez, a Venezuelan citizen. The video did not come from any deep-web snuff movie but from Instagram posts. Óscar Alberto Pérez was a Venezuelan police officer born in 1981, who worked for the military special forces unit CICPC (Cuerpo de Investigaciones Científicas, Penales y Criminalísticas) for 16 years. An ambiguous and atypical personality, he shared every moment of his life on social media. He could be seen parachuting with a dog in his arms, giving lessons at the police academy, bringing medicine to sick children, fighting against the corruption very present in his country, sending messages of love to his children, etc. With his GI Joe look, his blue eyes and his eccentric personality, he had become a very popular personality on the Venezuelan social media. His posts gave him the stature of an action movie character, which he became in 2015 when he played in the movie Muerte Suspendida, directed by Óscar Rivas, the role of a police officer investigating a rogue kidnapping that ends with a very Hollywood-style assault by special forces to free the hostage. The film was a great success in Venezuela and the director earned police protection after he received death threats from the corruption networks exposed in the film.

In 2017, Óscar Pérez's life changed dramatically when he became a leading figure in the Venezuelan government's protest against the political and economic crisis. Indeed, Venezuela has been undergoing a deep socioeconomic crisis since 2010, which began under the presidency of Hugo Chávez, and continues, even today, under the one of Nicolás Maduro, president of the Venezuelan Republic ${ }^{1}$ since 2013. A growing part of Venezuelans is living in extreme poverty due to inflation and the high cost of basic necessities. Faced with this situation, the opposition to Nicolás Maduro, which accuses him of economic mismanagement and authoritarian drift, attempted to set up a referendum for a presidential impeachment. But it was rejected by the National Electoral Council which is a pro-Maduro institution. Thousands of Venezuelans went to protest and called for the president's resignation. As the economic and social situation did not improve, and Nicolás Maduro refused to dialogue with the opposition, largescale demonstrations began to shake the country from January 2017. These protests were compounded by a constitutional crisis when, at the end of March 2017, the Supreme

1 Defining Nicolás Maduro as the president of Venezuela is not a political position on our part. His legitimacy is in fact questioned by part of the country's population and by a number of foreign states, which consider Juan Guaidó, a young deputy of the National Assembly who will be selfproclaimed president of the Venezuelan Republic on January 23, 2019, as the true representative of the Venezuelan people. If we qualify Maduro as president, it is to be as close as possible to the events surrounding the death of Óscar Pérez, because Juan Guaidó has so far not been recognized by the Venezuelan people but only by foreign political bodies. 
Court of Justice, also a pro-Maduro institution, dissolved the National Assembly. Many international observers regarded it as an attempted coup $d$ 'état.

On June 27, 2017, in the midst of the political crisis, Óscar Pérez threw four grenades from a helicopter to the Supreme Court of Justice in Caracas. The helicopter transporting him carried a flag with the words "350 Libertad," in reference to the Article 350 of the Venezuelan Constitution: "El pueblo de Venezuela, fiel a su tradición republicana, a su lucha por la independencia, la paz y la libertad, desconocerá cualquier régimen, legislación o autoridad que contraríe los valores, principios y garantías democráticos o menoscabe los derechos humanos." (The Venezuelan people, faithful to its republican tradition, to its struggle for independence, peace and freedom, must ignore any regime, legislation or authority that is contrary to democratic values, principles and guarantees or threatens human rights.). The attack by Pérez caused no casualties. He acted face to face and claimed responsibility for his act on Instagram shortly afterwards through various videos. In one of these videos, surrounded by five men, four of them masked, he called for a popular uprising. He said: "Somos nacionalistas, patriotas e institucionalistas. Esta lucha no es con el resto de las fuerzas estatales, es contra la tiranía de este gobierno." (We are nationalists, patriots and institutionalists. This struggle is not against state forces but against the tyranny of this government.). President Nicolás Maduro called the attack on the Supreme Court of Justice a terrorist act and Óscar Pérez became the most wanted man in the country. He was on the run for six months. This did not prevent him from appearing publicly on July 13, 2017 during a demonstration in Altamira and calling on the Venezuelan people, in front of the cameras of anonymous people and journalists, to bring down this "narco-government". On December 18 of the same year, he succeeded, with the help of fifty other rebels, in an operation against the National Guard. The attack again caused no casualties. Pérez and his acolytes took the weapons of the members of the National Guard before tying them up and filming them. They then published a video on social media in which they made fun of the guards and ridiculed them for their support to Nicolás Maduro's regime.

Óscar Pérez's escape ended on January 18, 2018, during a raid in the city of El Junquito, in which Óscar Pérez and his teammates (Daniel Enrique Soto Torres, Abraham Lugo Ramos, Jairo Lugo Ramos, José Alejandro Díaz Pimentel and Abraham Israel Agostini) as well as a pregnant woman and a child lost their lives. Six other people were arrested. Throughout the raid, Óscar Pérez alerted Venezuelan and international public opinion on the situation by posting videos on Instagram. Internet users followed the military operation, which lasted several hours. On numerous occasions, Pérez announced his intention to surrender, but the military group besieging him refused it. In these videos we can hear the sound of bullets whistling, grenades exploding, screaming, crying. Óscar Pérez's face is covering in blood as one publication follows another. We can 
hear the dialogue of the deaf between him and the special forces that are besieging the building. As Óscar Pérez says in one of the last videos published: "We warned that we were going to surrender, but they won't let us surrender, they want to kill us! [...] I want to ask the Venezuelans not to give up, to fight, to go out into the streets, it's time for us to be free!" In another post he bids farewell to his children. These videos were seen live by a large number of Venezuelans before the posts stopped and, a few hours later, President Nicolás Maduro confirmed the death of Pérez and his team members, describing them as "rebels" and "terrorists financed by Colombia."

The NGO Human Right Watch deplored "an extrajudicial execution" reminiscent of "the dictatorships in Argentina and Chile" (Human Rights Watch, 2018). Amnesty International, for its part, denounced an "illegal execution" (Amnesty International, 2018). The Venezuelan Episcopal Conference (CEV) has described the operation as a "horrible massacre" (Granado, 2018). Part of international opinion has also described the El Junquito raid as a "massacre" and severely criticized the Maduro regime. On social media, the hashtag \#0scarPerezHeroedelPueblo (Óscar Pérez, hero of the people) spread worldwide. In Venezuela, demonstrations took place the day after Óscar Pérez's death and on the first anniversary of his disappearance.

\section{THE ART PIECES}

The videos produced and disseminated on social networks by Óscar Pérez were the starting point for two artistic projects: a film directed by Romain Champalaune and a website put online on the platform of the British collective Forensic Architecture.

Romain Champalaune's movie Life and Death of Óscar Pérez won the Jury Prize at the Brive Film Festival in 2019. It is a medium-length film that goes back almost chronologically to Óscar Pérez's videos. The first part of the film is made up of videos of Óscar Pérez's life before the attack on the Supreme Court of Justice, which makes it possible to recontextualize his face, transformed into a figure tinged with the mythical aura of political martyrs. This first part is full of light, both in terms of content and luminosity of the images. In the middle of the film, as if to mark a real tipping point, the atmosphere of the film, just like Óscar Pérez's life, changes completely with the events of June 27, 2017. The videos are darker and take place more in nocturnal environments. Pérez is himself as if transfigured. His face, which could make you think of a toothpaste ad in the first part, becomes closed and serious. It is this new character that we will follow until the end of the film, until his death. The structure of the film invites a double viewing in order to measure the gap between the character of Óscar Pérez before and after his commitment against Nicolás Maduro's regime. The opening scene, for example, has a completely different meaning the second time it is viewed. We see Óscar Pérez, with his back turned to look in a mirror, shooting his revolver at a mannequin behind 
him. From the very beginning of the video, the tragic destiny of Óscar Pérez materializes before our eyes, as he shoots at his past, what is behind him is going to die.

If we emphasize on the images from before June 27, it is because they allow us to anchor Óscar Pérez in a different temporality from that of political events, and because it allows us to show the difference between this film and the second project we suggest studying, which is "The Killing of Óscar Pérez" by the British collective Forensic Architecture (2018). Even if part of their research is shown in the most important art institutions in the world, Forensic Architecture carries out a work of investigation between architecture and investigative technologies in order to propose studies on state violence or the violation of human rights. In this perspective, the members of the collective also work with judicial institutions such as the International Criminal Court of Human Rights, or NGOs such as Amnesty International. In 2018, in partnership with the English investigative magazine Bellingcat and Venezuelan journalists, they collected approximately seventy documents related to the El Junquito raid (social media videos, photographs, audio recordings leaked from police communications, official speeches, etc.) in order to investigate and determine the perpetrator of the extrajudicial killings of Óscar Pérez and his team members. Based on these documents, they created a website consisting of a $3 \mathrm{D}$ map and a timeline showing the probable development of the events of January 18, 2018. Visitors can browse the website to view or listen to the "evidence" gathered by the collective and locate themselves on the map from the geographical position where the documents were recorded.

We can then wonder about the status of an image produced on social media. Is it an evidence in itself or should we wait for artists, researchers and investigators to link it with other documents before it becomes an evidence? The administration of proof and the frameworks for its reception differ according to the disciplinary field mobilized, because the conceptions of "truth" and the expected ends of these practices also differ. But looking at the works of Forensic Architecture and Romain Champalaune, we can ask ourselves whether the boundaries are not becoming more and more permeable. In an age of big data and visual and textual hyperproduction, these artistic practices also teach us about how we can navigate the immensity of the "monster-archive" ("archivemonstre," Fraser, 2019) that Internet is. How do artists play with or subvert the logic of the Internet? And how can their work enable "counter-narratives" in the face of the dominant powers?

\section{ESTABLISHING THE EVIDENCE}

As Eyal Weizman writes in Penser l'image III (Weizman, 2017), the status of the image has changed with digital technology, and the multiplication of video and photo capture devices and smart phones. Until about thirty years ago, the images of conflicts we had 
access to were those taken by war reporters. They went into the field ${ }^{2}$, experienced the conflict, and had to take the right picture, the one that would mark the distant consciousness of the conflict. But today, in the digital age, "the rise of first-hand sources has broadened the perceptive horizon of conflicts. It has also allowed those involved to become unarmed actors rather than victims"3. (Weizman, 2017). A shift in the regime of representation has thus taken place, bringing a phenomenon of empowerment where everyone can become a producer of representations concerning him/herself or his/her environment. With these unarmed actors documenting conflicts, we can say that the question of the lack of representation, even if it remains a major issue, is less problematic than before. However, the ability to give everyone the opportunity to take images also upsets our surveillance regimes. We would no longer evolve in a panopticon, as Michel Foucault theorized after Jeremy Bentham, a system in which few people can monitor a large number of individuals, without the latter knowing when they are or are not being observed. We would have gone to the catopticon, a principle of surveillance, as theorized by Steve Mann, in which everyone can monitor everyone. In this broadening of the "perceptual horizon of conflict," the artist and the researcher are no longer confronted with an absence of representation but with a set of scattered representations of the same event taken from different points of view. He/she must then arrange them in order to give them meaning. Eyal Weizman calls this set of representations a "complex of images." To construct the overall image of the conflict requires going through this complex and "requires building architectural models in order to render images and videos to bring them together, to archive them and to put them in relation" 4 (Weizman, 2017). The overall image must always be created by assembling the images found (on the Internet, on television, in judicial reports, etc.), which represent only a tiny fraction of the event. It is only through this assemblage that one will be able to say something about the conflict and thus constitute the "evidence" necessary for one's judgment (legal, political or popular). An image as such cannot be a proof. To be an evidence, an image must be related to other texts and images in an ecosystem of discourse. For example, a picture of a concentration camp is not an evidence in itself. It is an evidence because it is part of a whole network of evidences, discourses and a common history. A person outside of this network, and having never heard of the Shoah, will only see it as a photo of a building like any other. Evidence then always needs to be established by the creation of a network of evidence. This is where

2 The idea that they needed to go into the field presupposes that they were always individuals from outside the conflicts that documented them. This may have given rise to a certain amount of controversy, around the photographer Kevin Carter for example, about a possible neocolonial aspect of the approach. We cannot develop here the ins and outs of such a reflection, but it seemed important to us to mention it.

3 Our translation

4 Our translation 
we find the tension between the captopticon and the panopticon: to hold power now is to possess the tools to reconstruct a "complex of images".

An image needs to be related and contextualized in order to become evidence. It must therefore be reinserted into its production and reception context to make it do something. A reconstructed image complex does not just show something; it is a document that can make people act. An image has this capacity to make us make decisions. This postulate of the agentivity of images is at the heart of the emergence of Visual Studies in the 1990s which, opposing the descriptive-interpretive methodology of images, decided to study the effects of images 5 . We limit this postulate by saying that images do not do things on their own, but we do things with images. It is then not a question of dealing with the power of the image but of acting through the image. We can then imagine that the individuals capturing the political events that they have in front of them with their mobile phone do not do it in an esthetic perspective but rather in the hope that their video will make act. However, their image alone cannot represent reality because it is already captured in the technical devices that fictionalize it ${ }^{6}$-the framing, the editing. It is then necessary to develop a research practice focused on the gathering of images, and the verification, localization and reconstruction of events by taking several points of view into account. This multiplication of points of view on the events can then help to dispel lies and misinformation. It is therefore in the thoughtful elaboration of an archive that evidence is constituted that can be acted upon, i.e. allow the rendering of a judgment in favor of one or the other party, set up the beginning of demonstrations or lead to the resignation of a political personality, for example. This archive also allows history to be written, because history, in order to be written, always needs archives on which to base itself. The archive always precedes the writing of history. The change in the media regime brought about by the Internet and social media allows everyone to question the words of the state authority, as well as the ones of historians or journalists, in the writing of daily life and history. Everyone can go in search of available documents from their computer in order to build evidence ${ }^{7}$.

5 The success of this idea of the performativity of images can be seen not only by the extent of the academic works devoted to the question but also by the passage of this idea outside the academic field, with journalists writing about a presumed role of images in stopping wars, for example.

6 As artist and director Hito Steyerl said apropos of her piece Red Alert: we are at "the end of video as a medium for representing something real. [...] Imagine that: the most real image didn't show anything at all."

7 This investigative approach by everyone has been staged in a very enlightening way this year in the micro-series Don't F**k with Cats: Hunting an Internet Killer by Mark Lewis broadcast on Netflix. In this series, a few Internet users go on a search for a young man killing kittens on video. Their investigation will allow them to discover the identity of the latter and to collaborate with the police when he turns out to be the Canadian murderer Luka Magnotta. 
We can say that Romain Champalaune's film and Forensic Architecture's website allow us to reconstruct an event by assembling videos and additional information (topography, chronology, audio recordings) about it. They constitute an archive of the Óscar Pérez case that allows us to get to know the event, and to preserve the material traces that risk disappearing due to their technological dependence (to a format, a platform like YouTube, etc.). For example, the Instagram account on which Óscar Pérez published his videos was deleted by the platform. The videos that still exist now are the archives created by the two artists, and Instagram and YouTube accounts of anonymous web users who republished them. These backups in the form of republication not only save these videos from oblivion but also allow future work on these documents for historians, journalists or anyone else. It is these backups that allow us to write this article today. They prevent, at least for as long as they exist, Óscar Pérez to become "a gap in the archive" (Schenk, 2014). As archive theorist Dietmar Schenk says: "The function of archives is to preserve the historical material from which facts are uncovered, demonstrated and constantly verified, corrected and reinterpreted." (Schenk, 2014). But this, of course, requires that the videos are not lost and that they are recorded and archived, in the professional sense of the word, because an existence on the Internet does not mean visibility and a sufficient basis for historians to be able to work with, who will then have to recreate the complex of imagers themselves from the traces found on the Internet before being able to set to work.

The history of the archive and the history of writing are inseparable. Without a written archive, without a record of the fixed past, we remain in the oral transmission of history. There is therefore a concentration of power in the hands of those who possess the writing and those who constitute the archive. As the old saying goes: it is always the victors who write history. However, this is changing today with the visual regime. The very essence of video, which has a "real effect"-a "ça a été" (Barthes, 1984)-superior to that of writing, as well as the ease with which anyone can produce images, forces us to consider the archive differently. David Bolter and Richard Gruisin (1999) wrote that the power of a medium depends, above all, on its degree of mimesis: if a new medium can supplant an existing one, it is because it offers a more direct contact or a sharper vision of the real. Video does not supplant writing in the constitution of archives, because they are always composed of indexes and written descriptions, but it plays an essential role in the writing of contemporary history because it allows us to document daily life and major social events with an important effect of reality.

If the artistic appropriation of videos produced on social networks raises many ethical questions, it can be said that, in this case, the essence of Óscar Pérez's videos is to be shareable and disseminated as widely as possible in order to alert people to the public situation. As André Gunthert says, the image today is no longer marked by its capacity for "technical reproducibility," immediate and infinite reproducibility being 
one of the characteristics of "digital ontophany," (Vial, 2013) but rather by its "digital appropriability": "The digital ecology not only encourages the production of remixes or rebroadcasts; it establishes appropriability as a character of cultural objects, which are only worthy of attention if they are shareable"8 (Gunthert, 2015). These videos are therefore like bottles thrown to the sea to alert us. The role of the artist-researcher is then to become a "historian of the present", helping to write history through his/her work of research, and linking images and other documents. This role is the most important in the age of the "monster-archive" in which we live, as Marie Fraser theorized. The idea of monstrosity that she mobilizes is borrowed from Pierre Nora's "monster event," who in a 1972 article wrote that

the mass media now have a monopoly on history. In our contemporary societies, it
is through them and by them alone that the event strikes us, and cannot avoid us...
[they] act not only as a means by which events are relatively independent but as
the very condition of their existence. [...] For there to be an event, it must be known.
[...] The mass media have thus turned history into aggression, and made the event
monstrous10. (Nora, 1972)

Marie Fraser (2019) then wonders:

If the monster archive transforms knowledge into mere data and if the library is replaced by the big data, is it not at the same time subjecting knowledge to intelligibility? Faced with the extraordinary storage and indexing capacity of databases, are we not facing an inflation of the archive? And doesn't the speed at which digital technology can expand and accumulate data to the point of overload make it obsolete? Digital technologies not only produce an incessant and infinite mass of information, but their storage capacity also generates a paradoxical reversal of memory".

What follows from reading this text by Marie Fraser is that the archive constituted by the big data is a power structure that excludes individuals, and humans in general, from understanding the archive. Artists and researchers such as Forensic Architecture and Romain Champalaune have been working to restructure the "monster-archive" in order to make it accessible, thereby realizing the program that Paul Klee dedicated to art: make the invisible visible. Their work crosses the attentional polarizations ${ }^{12}$ set up by the

8 Our translation.

9 Expression used by Eyal Weizman during a public presentation in November 2019 at the Bibliothèque Nationale du Québec in Montreal.

10 Our translation

11 Our translation.

12 In a previous article, we proposed to consider attentional polarizations on the Internet as a fringe oligopoly structure. A large part of the attention capital of users seems indeed to be captured by only a few sites (Facebook, Google, Instagram, YouTube, etc.). And this structure is played out on a platform scale, where certain content and certain accounts capture a large part of users' attention. See Deneuville (2020). 
"monster-archive," platforms and other forms of algorithmic governmentality in order to make us pay attention to content that is in danger of disappearing. They defeat the logic of algorithms that can only do mass data processing without creating semantic and event-driven coherence. Artists themselves create meaning through the arrangement of the archive.

However, Romain Champalaune's film and the Forensic Architecture website act differently to build the story of Óscar Pérez. This difference stems from their creative medium but above all from their intentions. Champalaune's work is a film with the idea of building Óscar Pérez as a character. Thus, the film follows his "descent into hell." The director builds with him an archetypal figure of a Greek tragedy hero sacrificing himself for the honor of his country. For its part, Forensic Architecture is in a process of "reconstruction" of reality in order to find the "truth" of the event. It is a question of understanding what really happened around the death of Óscar Pérez. The layout of the website does not only have esthetic and narrative virtues: it exists to bring out a certain type of knowledge and understanding that may have an effect on the political and judicial reality. The website, moreover, takes its place within an economy that allows it to be freely accessible. Whereas the movie by Champalaune is only available at film festivals or for one-off screenings, which greatly reduces its visibility.

\section{MEMORY AND COUNTER-NARRATIVE}

In both cases, as we have said, it is still a question of building a non-institutional archive. In two recent articles (Alloa, 2014 and 2018), Emmanuel Alloa establishes a link between sousveillance and storytelling. He takes as an example the cameras that American police officers are now equipped with. He writes that being in a sousveillance regime does not mean that the truth will be found, access to it being a millennial philosophical problem. But now the perpetrators of violence and their victims will be fairly armed in a world of fictional constitution and post-truth. Anonymous individuals who previously only had to accept the gaze and the discourses that were cast upon them are now in possession of tools to produce discourses and disseminate them to propose counter-narratives. Even if an image alone can create a shock that makes it possible to reconsider the reality ${ }^{13}$, in the cases investigated by Forensic Architecture, it is the complex of images that must be constituted in order to set up a rigorous demonstration capable of making the narratives of the powers crack. This writing of history through the confrontation of images, through the discussion of different points of view, can also be found in the daily practices of digital

13 One can think, for example, of many images that have marked the history of photojournalism, and that have been able to mark the collective imagination and influence of political decisions: the little girl in the Napalm Kim Phuc photographed by Nick Ut or the photo of little Alan Kurdi by Nilüfer Dumir. 
technologies. For example, in the Spanish Wikipedia page of the article on Óscar Pérez, in the "Discusión" tab, one can see the contributors exchanging and debating on the writing of the event and on the words to be used, especially on the use of the word "massacre" to talk about the raid on El Junquito. These practices raise important epistemological questions about the way we write history. Each of them, whether artistic or amateur, constructs a narrative of Óscar Pérez's life and death from the videos and information found on the Internet and social media. They also allow a question to emerge and an audience to debate, and to keep on debating, and thus write the story.

The added value of art is to act as an additional dimension of the field studied. In Ces opérations d'écriture qui ne disent pas leur nom, the poet and theorist Franck Leibovici indeed qualifies documental art and poetry as $(n+1)$. Art brings an additional dimension, without the latter having to be placed on a higher plane from a moral point of view, allowing the potentialization of documents and the links between these documents and others. This potentialization can be understood in the ability to succeed, by arrangement in other words, to make documents read something other than what automatic or professional reading reads. This is exactly what Romain Champalaune and Forensic Architecture do. Their works lead us to see in documents realities and discourses that existed only in the state of potential, only waiting for an actualization that the reading of a Twitter timeline does not allow. We could then say that the documents are waiting for their potential to be maximized. Without the work of assembling and constituting them as evidence, they would only be proto-archives waiting for discourse and meaning. They are meaningless without this potentialization. Franck Leibovici speaks of a technique for "unfreezing" a document in order to bring out its "most relevant features." The role of artists is not only to create an archive but also to think about how to shape it, because it is from this shaping that knowledge can emerge. The choice of the website in the case of Forensic Architecture, for example, allows the event to be spatialized and temporalized, and thus the crime scene to be reconstructed. There is something of the order of demonstration in this formatting, as one can speak of a mathematical demonstration. If Forensic Architecture's piece works on the idea of convincing, one could say that Champalaune's film is based on a certain form of persuasion. The film, through its relation to fiction, temporality and the showing of Óscar Pérez's videos before his revolt, acts on viewers' affects and leads them to feel revolt and injustice in the face of the situation presented to them.

Through this ability to shape, the collaboration between professional archivists and artists can be fruitful for both fields of activity. Artists as such possess a skill in understanding images and their constitution that can help historians, archivists or even jurists to consider differently the documents they manipulate or create. Art gains by questioning its paradigm of autonomy detached from the social and political sphere. This is what the work of Forensic Architecture and Romain Champalaune shows, as well as the work of a series of other greatly stimulating artistic projects of recent 
years, such as Frank Leibovici's Bogoro which, with the jurist Julien Seroussi, revisits the documents produced by the International Criminal Court around the trial of two Congolese militiamen, Germain Katanga and Mathieu Ngudjolo, accused of war crimes and crimes against humanity.

\section{CONCLUSION}

The work of these two artists thus allows us to reconsider the change in the regime of representation, and to see how the artist can borrow the tools of investigation to create a work as well as evidence. This may take us back to the figure of Auguste Dupin in Edgar Allan Poe's short story The Mystery of Marie Roget, in which this detective uses real newspaper clippings to find the culprit in Marie Roget's murder. But their works also allow us to consider how this investigative work must be seen in a new light with, on the one hand, the possibility for anyone to produce documents that are just waiting to be constituted as evidence, and, on the other hand, the "monster-archive" that this visual hyperproduction sets up. However, these works also testify to a willingness, which we find not only in more and more young artists and poets but also researchers, to rub shoulders with reality through the documents produced by institutions or by anonymous individuals. Beyond esthetic trends and an individual political will, these practices question a potential esthetic and epistemological upheaval within the field of art or research that is still waiting to be conceptualized.

\section{REFERENCES}

Alloa, E. (December 30, 2014). La transparence dans le viseur américain. Libération. https://www.liberation.fr/planete/2014/12/30/la-transparence-dans-leviseur-americain_1171958

Alloa, E. (March 2, 2018). La nouvelle guerre du storytelling: qui surveille qui? Le Magazine littéraire.https://www.nouveau-magazine-litteraire.com/idees/nouvelle-guerre -storytelling-qui-surveille-qui .

AmnestyInternational.(January 17,2018).Venezuela:Statemustrespondfordeadlysecurity operation. https://www.amnesty.org/en/latest/news/2018/01/venezuela-statemust-respond-for-deadly-security-operation/

Barthes, R. (1980). La chambre claire: note sur la photographie. Gallimard.

Bolter, J.D. \& Grusin, R. A. (1999). Remediation: understanding new media. MIT Press.

Couston, J. (April 2019). À voir sur Télérama: “Vie et mort d'Oscar Pérez", de Romain Champalaune, Prix du jury au festival de Brive. Télérama. 
Deneuville, A. (2020). S'approprier Twitter en artiste: une pratique littéraire en question. Communication and languages, 203.

Fiorella, G. \& Leroy, A. (May 2018) "We are going to surrender! Stop shooting!": Reconstructing Óscar Pérez's Last Hours. Bellingcat. https://www.bellingcat. com/news/americas/2018/05/13/we-are-going-to-surrender-stop-shootingreconstructing-oscar-perezs-last-hours/.

Forensic Architecture. (2018). The killing of Óscar Pérez. https://forensic-architecture. org/investigation/the-killing-of-oscar-perez

Fraser, M. (2019). L'archive monstre: de l'ars memoria au big data in Dallet, J-M and Gervais, B. Architectures de mémoire. Presses du réel.

Ganascia, J-G. (October 2010). The Great Catopticon. http://www-poleia.lip6.fr/ ganascia/ Catopticon.

Granado, 0. (January 18, 2018). CEV pide al Gobierno iniciar una investigación «objetiva» de la «masacre de El Junquito». TalCual. https://talcualdigital.com/cev-pide-algobierno-iniciar-una-investigacion-objetiva-de-la-masacre-de-el-junquito/.

Gunthert, A. (2015). L'image partagée. La photographie numérique. Textuel.

Hanna, C. (2010). Nos dispositifs poétiques. Questions théoriques.

Human Rights Watch. (January 17, 2018). Venezuela: HRF condena ejecución extrajudicial de Oscar Pérez. https://mavenroundtable.io/humanrightsfoundation/americas/ venezuela-hrf-condena-ejecución-extrajudicial-de-oscar-pérez-3MCMVvzfoETQ7kTA4U9vQ.

Leibovici, F. (2007). Des documents poétiques. Al Dante.

Leibovici, F. (2020). Des opérations d'écriture qui ne disent pas leur nom. Questions théoriques.

Nora, P. (1972). L'événement monstre. Communications, 162-172.

Schenk, D. (2014). Pouvoir de l'archive et vérité historique. Écrire l'histoire. http:// journals.openedition.org/elh/463

Vial, S. (2013). L'être et l'écran: comment le numérique change la perception. Presses Universitaires France.

Weizman, E. (2017). L'image en conflit. La violence au seuil de sa détectabilité in Alloa, E. Penser l'image. 3: Comment lire les images? Presses du réel. 